FedUni ResearchOnline

http://researchonline.federation.edu.au

This is the peer-reviewed version of the following article:

Bhattacharya, R., et al. (2016). "Ecological response to hydrological variability and catchment development : Insights from a shallow oxbow lake in Lower Mississippi Valley, Arkansas." Science of the Total Environment 569-570: 1087-1097.

Which has been published in final form at: http://doi.org/10.1016/j.scitotenv.2016.06.174

Copyright (C) 2016 Australian and New Zealand Society of Cardiac and Thoracic Surgeons (ANZSCTS) and the Cardiac Society of Australia and New Zealand (CSANZ). Published by Elsevier B.V. All rights reserved. This manuscript version is made available under the

CC-BY-NC-ND 4.0 license http://creativecommons.org/licenses/by-nc-nd/4.0/ 


\section{Ecological response to changing hydrological variability and catchment development: insights from a shallow oxbow lake in Lower Mississippi Valley, Arkansas}

Article in Science of The Total Environment · November 2016

DOI: 10.1016/j.scitotenv.2016.06.174

CITATIONS

0

5 authors, including:

\section{Sonja Hausmann}

41 PUBLICATIONS 617 CITATIONS

SEE PROFILE

\section{Peter Gell}

Federation University Australia 89 PUBLICATIONS 1,311 CITATIONS

SEE PROFILE

\section{J. Bradford Hubeny}

Salem State University

121 PUBLICATIONS 207 CITATIONS

SEE PROFILE

Jessica L. Black

Heritage University

22 PUBLICATIONS 123 CITATIONS

SEE PROFILE 


\title{
Ecological response to hydrological variability and catchment development: Insights from a shallow oxbow lake in Lower Mississippi Valley, Arkansas
}

\author{
Ruchi Bhattacharya ${ }^{\mathrm{a}, *}$, Sonja Hausmann ${ }^{\mathrm{b}}$, J. Bradford Hubeny ${ }^{\mathrm{c}}$, Peter Gell ${ }^{\mathrm{d}}$, Jessica L. Black ${ }^{\mathrm{e}}$ \\ a Environmental Dynamics, Department of Geosciences, University of Arkansas, Fayetteville, AR 72701, USA \\ b Academy of Natural Sciences of Drexel University, Philadelphia, PA 19103, USA \\ c Department of Geological Sciences, Salem State University, Salem, MA 01970, USA \\ d Faculty of Science and Technology, Federation University Australia, Ballarat, Australia \\ e Heritage University, Toppenish, WA 98948, USA
}

\section{H I G H L I G H T S}

- Impacts of hydrological and land use changes on a floodplain lake were evaluated.

- Diatom and geochemical stratigraphic records from floodplain lake were utilized.

- Anthropogenic stressors promoted ecological regime shift in the floodplain lake.

- Utility of paleolimnological methods to understand ecological evolution was stressed.

- Study flags the need to monitor these wetlands under the Ramsar Convention.
GRA P H ICA L A B S T R A C T

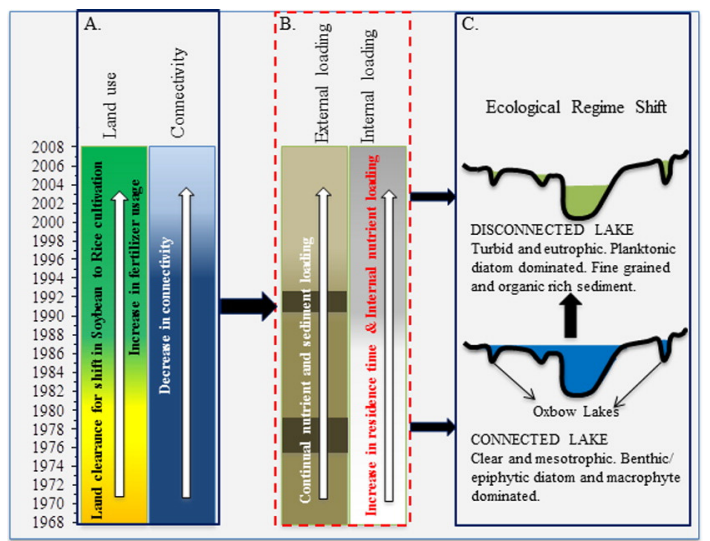

\section{A R T I C L E I N F O}

\section{Article history:}

Received 22 April 2016

Received in revised form 20 June 2016

Accepted 21 June 2016

Available online $\mathrm{xxxx}$

Editor: Jay Gan

\section{Keywords:}

Hydrological connectivity

River-floodplain ecosystem

Regime shift

Diatoms

\begin{abstract}
A B S T R A C T
The ecological response of shallow oxbow lakes to variability in hydrology and catchment development in large river floodplain ecosystems (RFE) in Arkansas remains largely unknown. Investigating these responses will advance our understanding of ecological evolution of oxbow lakes in response to the major environmental drivers, which will establish baseline conditions required to develop effective management practices for RFE.

In this pilot study, we examined the potential of using a dated surface sediment core from Adams Bayou, a floodplain lake located within the Cache-Lower White River Ramsar site in SE Arkansas. Stratigraphic records of diatoms and sediment geochemistry were used to ascertain variation in Adams Bayou's ecological condition. During 1968-2008, in response to hydrological and anthropogenic changes, Adams Bayou's diatom assemblages progressed from predominantly benthic (Gomphonema parvulum and Meridion circulare) to primarily planktonic assemblage (Aulacoseira granulata and Cyclotella meneghiniana), along with a decrease in magnetic susceptibility (k) and \% silt. Statistical analyses reveled that during 1968-2000, higher hydrological connectivity and catchment
\end{abstract}

\footnotetext{
* Corresponding author.

E-mail addresses: ruchi.bhattacharya@gmail.com (R. Bhattacharya), tonisonja42@gmail.com (S. Hausmann), bhubeny@salemstate.edu (J.B. Hubeny), p.gell@federation.edu.au (P. Gell).
} 
XRF

Catchment alteration

Water quality

Ramsar alterations drove Adams Bayou's ecosystem. After 2000, lower hydrological connectivity and increase in cultivation were the major drivers. The potential impact of increasing air temperature was also noted.

The shift in Adams Bayou from a connected, clear, mesotrophic state to a relatively isolated, turbid and nutrient enriched state is consistent with regime shift models and highlights its sensitivity to a combination of environmental stresses prevalent in the catchment. Although fluvial systems pose challenges in establishing clear chronologies, oxbow lake sediments can be a effective paleoecological archives. Our work provides clear evidence for the change in the ecological character of this wetland of international significance and flags the need for a wider assessment of water bodies across this site under obligations to the Ramsar Convention.

(c) 2016 Elsevier B.V. All rights reserved.

\section{Introduction}

River floodplain ecosystems (RFEs) are one of the most altered ecosystems in the world (Tockner et al., 2010). River modifications and extensive row-crop cultivation have disrupted the duration of surface connectivity, and made the floodplain a non-point source of sediment and nutrients, with severe ecological and biogeochemical implications for the RFEs (Sparks, 1995; Nilsson and Berggren, 2000; Tockner et al., 2011). Furthermore, rising air temperature and hydrological extremes, as a consequence of global change, have promoted algal blooms and affected nutrient cycling in RFEs (Chen et al., 2013; Finlayson et al., 2016). The lack of regular monitoring efforts presents large knowledge gaps regarding the baseline conditions in the RFE and their ecological evolution through time (Hausmann et al., 2011; McCluney et al., 2014).

In large, meandering RFEs, the oxbow lakes serve as sinks for river and catchment inputs of sediment, nutrients and biota when high flows connect river and lake (Thomaz et al., 2007; Rodríguez et al., 2011). Oxbow lakes are therefore sensitive to hydrological alterations and local catchment disturbances (Brugam et al., 2003; Wolfe and Smol, 2005). Paleolimnological investigations, particularly including fossil diatoms, sediment geochemical and physical characteristics from oxbow lakes can act as excellent indicators of these multiple stressors, and thus, can be used to establish past floodplain ecological conditions (e.g., Gell et al., 2002; Wolfe and Smol, 2005; Chen et al., 2011; Grundell et al., 2012; Kattel et al., 2015). Despite their potential, oxbow lakes are still largely unexplored as paleoecological archives in highly cultivated RFEs located in the humid subtropics, likely due to chronological challenges of sediment records in these dynamic systems (Gell et al., 2005; Reavie and Edlund, 2010). Importantly, in un-glaciated parts of the south central United States, oxbow lakes are the only natural lakes that offer the best available means to reveal the influence of prominent drivers on RFEs and establish baseline information, which could be further used to develop effective management strategies.

Our study focused on the Lower White River Floodplain (LWRF), a large, temperate RFE, located within the Lower Mississippi Valley (LMV) in SE Arkansas, USA (Fig. 1). The LWRF was listed under the Ramsar Convention as the Cache-Lower White River site in 1989 and has experienced a long history of river modification and catchment alterations (MacDonald et al., 1979; USFWS, 1994; Scott et al., 1998). However, the current and background ecological information for the

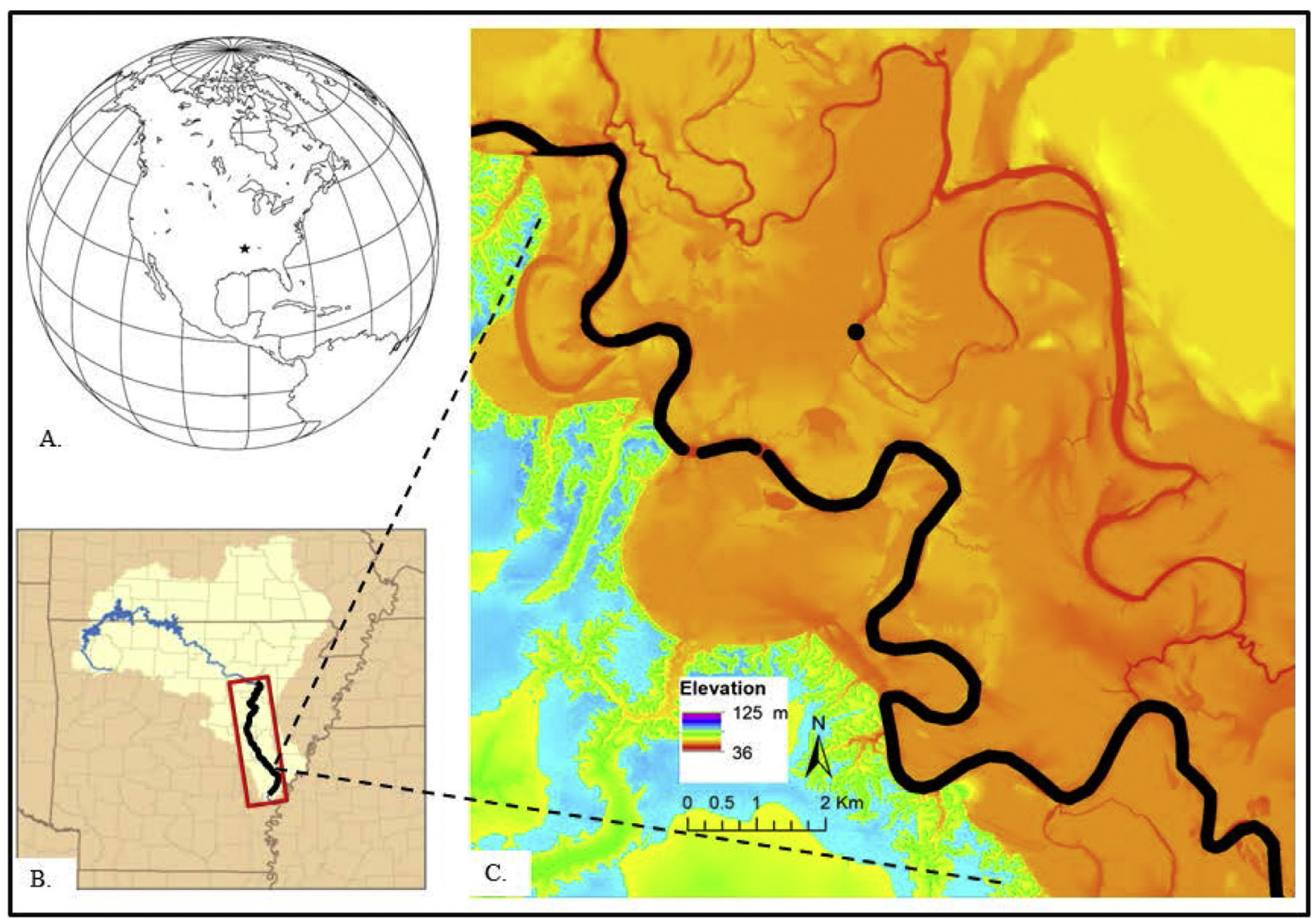

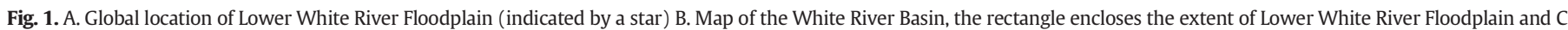
Inset shows the location of Adams Bayou (indicated by a filled circle). Main stem of Lower White River is also indicated by thick black line. 
LWR oxbow lakes is scant, and the effects of alterations in hydrology and catchment variability on the ecology of LWRF, as required by the Ramsar convention (Finlayson et al., 2016; Newall et al., 2016), are yet to be quantified.

We hypothesized that floodplain lake sediment archives can aid in understanding the ecological evolution of the LWRF ecosystem in response to hydrologic variability and catchment alterations. The stratigraphic record of sub-fossil diatom assemblages, geochemical characteristics were used in combination with the time series of hydrological connectivity and catchment alteration to gain insights regarding the combined influence of changing catchment/river inputs on the ecological response of the oxbow lake between 1968 and 2008. Since, global change projections anticipate significant increases in air temperature and extreme hydrological events for the most part of United States (IPCC, 2014), the possible influence of climate variability as driver of the oxbow lake ecosystem was also considered using air temperature and precipitation records. Finally, the current study was conducted to assess the resilience of LWRF to multiple environmental stressors; and represents a critical pilot to begin assessment of the status of this Ramsar site, one of the thirty-six across the USA.

\section{Study site}

The White River is the largest drainage basin in the state of Arkansas and a tributary to the Mississippi River. The Upper White River (UWR) is a mountainous stream that flows through the Ozark Mountains; while the Lower White River (LWR) is an 8th order meandering river confined within the LMV in SE Arkansas (Smith and Saucier, 1971). The LWR forms a broad floodplain with $>400$ oxbow lakes that experience various degrees of surface connectivity during the annual floods (USFWS, 2010; Bhattacharya, 2012). The upstream section of the Lower White River Floodplain (LWRF) is predominantly agricultural, while the downstream section of the LWRF is protected as the White River National Wildlife Refuge (WRNWR; USFWS, 2010), one of the largest remaining, continuous, stretches of bottomland hardwood forests in the LMV (U.S. National Ramsar Committee, 2009).

For the current study, sediment cores were collected from Adams Bayou Lake located within the WRNWR (Fig. 1). Adams Bayou is surrounded by floodplain forest, but receives agricultural inputs via overland flooding and a paleo-channel that borders agricultural fields (Bhattacharya, 2012). Adams Bayou floods annually, and so is representative of the majority of lakes within the LWRF. Adams Bayou is situated at a distance of $\sim 2300 \mathrm{~m}$ from the White River and at an elevation of 2$\mathrm{m}$ above river bank-full elevation. The average depth of the water column is $3.5 \mathrm{~m}$ and the lake spans $\sim 2.8 * 10^{-4} \mathrm{~km}^{2}$. Due to lack of previous study on this lake, limited information is available regarding lake conditions. The limnological data collected during sediment sampling showed that Adams Bayou was nutrient rich (total phosphorus: $212 \mu \mathrm{g} / \mathrm{l}$; total nitrogen: $580 \mu \mathrm{g} / \mathrm{l}$ ) and slightly turbid (total dissolved solids: $150 \mathrm{mg} / \mathrm{l}$ ) after a long connectivity event.

\subsection{Anthropogenic alterations}

The UWR has five flood-control and hydroelectricity dams that were constructed between 1950 and 1965. The dams have decreased the magnitude of flooding, lowered the frequency of low flows and increased the duration of river-floodplain connectivity (Craig et al., 2001; Lin, 2009). The LWRF is also confined by 150 miles of flood control levees that were first constructed in the early 1900s and later extended downstream (Lin, 2009; USFWS, 1994). The levees have greatly increased floodplain inundation depth and permanently isolated major parts of the LWRF (USFWS, 1994; USFWS, 2008; King et al., 1998). In 2004, a lock and dam was also constructed near the confluence of the Lower White and Lower Mississippi Rivers, which further increased water levels and floodplain hydro-period in the LWRF (USFWS, 2008).
The LWRF has also been subject to major land clearing since the early 1900s for timber harvesting and agriculture (MacDonald et al., 1979; USFWS, 1994). In the 1950-60s, the construction of dams and levees sparked the large-scale conversion of floodplain forests into agricultural lands, largely used for soybean production (USFWS, 1994; USFWS, 2008). Most recently, the major increase in cultivated acreage occurred in the late 1970s (Fig. 2A) to accommodate the dramatic expansion in rice cultivation (Scott et al., 1998; Wilber et al., 1996), which was accompanied with high applications of fertilizer (Fig. 2B), and irrigational stress on the regional water resources.

\section{Methods}

\subsection{Hydrological connectivity, catchment alteration and climate records}

The influence of hydrological variability on the ecological character of Adams Bayou was explored by calculating the duration of river-lake surface connectivity using methods described by Lesack and Marsh (2010). For this purpose, we first estimated the river elevation $\left(E L E V_{R}\right)$ at bank-full discharge for a point adjacent to Adams Bayou. The $\mathrm{ELEV}_{\mathrm{R}}$ was obtained from USGS digital elevation model (DEM, $10 \mathrm{~m}$ resolution, $1 / 3$ arc-second). ESRI Arc GIS 10.0 software was used to create half-meter inundation contours on the DEM starting from $\mathrm{ELEV}_{\mathrm{R}}$ until Adams Bayou was completely inundated. The elevation at which the inundation contour first connected to Adams Bayou was taken as the lake sill elevation $\left(\mathrm{ELEV}_{\mathrm{L}}\right)$. The duration of connectivity between LWR and Adams Bayou was then calculated as the number of days, for which the river elevation from the nearest, upstream USGS gaging station $\left(\mathrm{ELEV}_{\mathrm{G}}\right)$ was equal to or higher than $\operatorname{ELEV}_{\mathrm{L}}$. The duration of connectivity was corrected for the elevation difference between $\mathrm{ELEV}_{\mathrm{G}}$ and $\mathrm{ELEV}_{\mathrm{R}}$. The time series of duration of river-lake connectivity (Fig. 2A) was calculated for the period of 1968-2008 and compared with the diatom stratigraphy. The record of total area under cultivation and the total annual fertilizer usage were used as a proxy for catchment alteration (Fig. 2B; USDA, 2016). Also, to assess the potential effect of climate variability on the fossil diatom assemblages, total precipitation $(\mathrm{cm})$ and average air temperature $\left({ }^{\circ} \mathrm{C}\right)$ records (Fig. $\left.2 \mathrm{C}\right)$ were accessed for the duration of 1968-2008 (NOAA, 2014).

\subsection{Sediment sampling and analyses}

Two adjacent gravity cores (lengths $36 \mathrm{~cm}$ and $60 \mathrm{~cm}$ ) were extracted from Adams Bayou in August 2008 using an UWITEC $®$ gravity corer with hydraulic core catcher. The sediment/water interface was kept intact. The $36-\mathrm{cm}$ core was extruded in $1-\mathrm{cm}$ sections in the field and stored in Whirl-pak ${ }^{\circledR}$ bags. The sediment samples were exported to the laboratory at $4{ }^{\circ} \mathrm{C}$ and used for diatom and organic matter analysis. $210 \mathrm{~Pb}$ and $137 \mathrm{Cs}$ were measured on 16 sediment depths spanning the $60 \mathrm{~cm}$ of the second core. Analysis was done by direct gamma assay in the Liverpool University Environmental Radioactivity Laboratory using Ortec HPGe GWL series well-type coaxial low background intrinsic germanium detectors (Appleby et al., 1986). The sedimentation rates were calculated by constant rate of supply (CRS) model using 1963 as a chronological marker (Appleby, 2001).

For diatom analyses, twenty-two sediment depths were selected from the $36-\mathrm{cm}$ core. Diatom frustules were prepared by heating the sediment samples with $30 \% \mathrm{H}_{2} \mathrm{O}_{2}$ and $10 \% \mathrm{HCl}$. The digested samples were centrifuged, and a known volume of microspheres were added to the supernatant and mounted permanently on microscope slides with Naphrax ${ }^{\circledR}$ (Battarbee et al., 2001). At least three hundred diatom valves per slide were counted where possible. Additional slides were counted for sediment depths with low diatom concentration. Diatom identification was conducted at $1000 \times$ magnification using a Leica DM 2500 microscope with differential interference contrast. Diatom valves were identified to species level where possible; others were only identified to genus level e.g. Meridion spp. Taxonomy was based on 


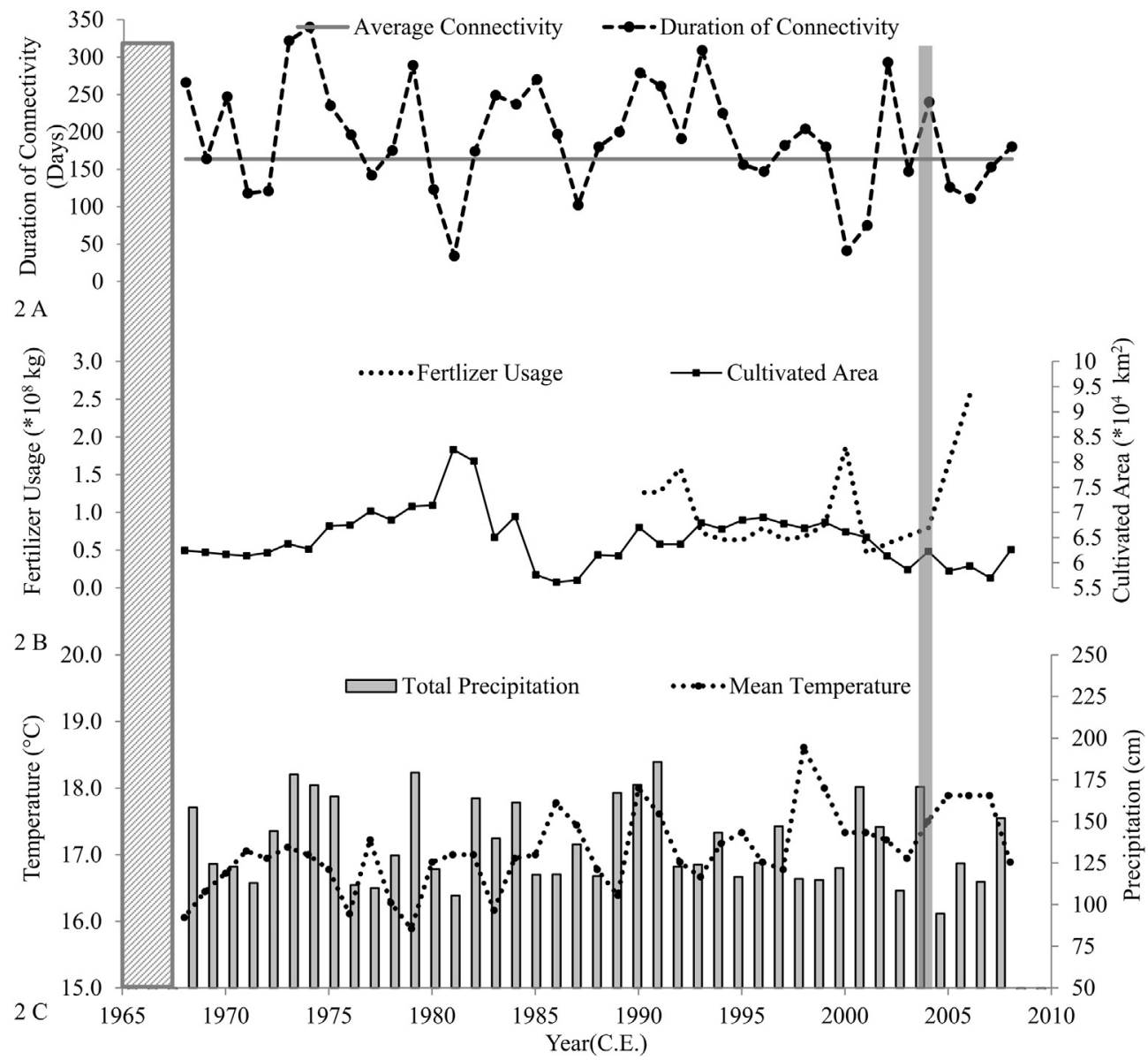

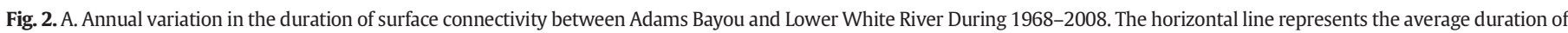

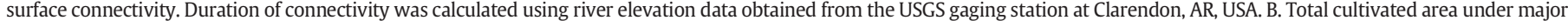

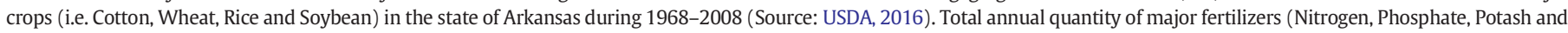

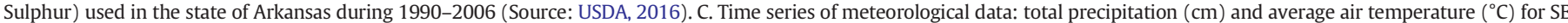

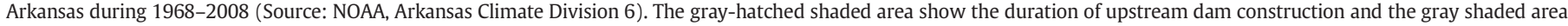
shows the duration of downstream lock and dam.

Krammer and Lange-Bertalot (1986-1991); Patrick and Reimer (1966, $1975)$ and Hustedt $(1930,1977)$. The diatom valves were expressed as relative abundances. Diatom accumulation rates (DAR) were also calculated for the total and planktonic portion of the diatom valves and used as an estimate of productivity (Anderson, 1989).

For geochemical analyses, the $60-\mathrm{cm}$ sediment core was split and logged at the Limnological Research Centre, University of Minnesota (LRC). The GeoTek Multi Sensor Core Logger (MSCL) was used to measure the volume magnetic susceptibility (MS; k) at 1-cm increments. Mass magnetic susceptibility (MS; chi) was calculated from MS (k) after adjusting for changes in bulk density. The sediment core was also scanned with X-ray Fluorescence (XRF) with an ITRAX-XRF scanner at 1-cm increments at the Large Lakes Observatory, University of Minnesota. The grain size analysis was conducted at LRC using Horiba Grain Size Analyzer LA-920. Prior to analysis, the sediment samples were pretreated to remove organic matter, carbonate and biogenic silica. The percent loss-on-Ignition (LOI) were measured from the sediment samples extruded in the field and from the adjacent sediment core samples by calculating the \% weight loss on heating at $105^{\circ} \mathrm{C}$ overnight and at $550{ }^{\circ} \mathrm{C}$ for $4 \mathrm{~h}$, respectively (Heiri et al., 2001). The LOI data were used to calculate the organic carbon accumulation rates (OC MAR). First, LOI was converted to \% organic carbon (OC) by multiplying with correction factor of 0.469 (Dean, 1974; Downing et al., 2008). Later, OC was multiplied with SAR for each sediment interval to obtain OC MAR. Similarly, the remaining \% inorganics was multiplied by SAR and converted to Inorganic MAR. The LOI was also used to cross correlate the two cores
(Supplementary Fig. 1). Overall, we used MS and Inorganic MAR as proxies for catchment alteration (Dearing, 1999; McLauchlan, 2003), \% silt as a proxy for hydrological connectivity (Liu et al., 2012; Chen et al., 2013), and Calcium and OC MAR as proxies for lake productivity (Meyers, 1997; Heath and Plater, 2010).

\subsection{Data analyses}

The detrended correspondence analysis (DCA) ordination technique was used to assess the length and direction of the diatom dataset (ter Braak, 1986; Jongman et al., 1995). Only the species present in at least two samples with abundance $>1 \%$ were included in the ordination. The diatoms were square root transformed and rare taxa were downweighted prior to the ordination analysis (ter Braak and Šmilauer, 2002). As the length of floristic gradient was $>2$ standard deviations, canonical correspondence analysis (CCA) - a constrained ordination method was used to explore the relation between the diatom assemblages and environmental variables. Prior to analysis, the environmental were centered, standardized and log transformed to achieve normal distribution. Variance inflation factor $(>10)$ was used to remove redundant variables. Step-wise selection method with 999 Monte Carlo permutation tests $(p<0.05)$ was used to determine a subset of environmental variables that significantly explained the maximum variance in the diatom data set. Variance partitioning was conducted to ascertain the percent variance uniquely explained by each variable. Further, we statistically tested the presence of regime shifts in the diatom 
assemblage using the "changepoint" library in R (Killick and Eckley, 2014). The Akaike information criterion (AIC) was used as the penalty criteria to identify any significant changes in mean and variance in the DCA axis 1 . The diatom assemblages were also partitioned into statistically significant zones by constrained incremental sum-of-squares-clustering (Grimm, 1987). The ordinations were conducted using "vegan 2.3-1" package in $\mathrm{R}$ ( $\mathrm{R}$ developmental team, 2008; Oksanen et al., 2008). The ordination results were plotted using CANODRAW 4.5 (Smilauer, 1992). All the stratigraphic plots were developed using the C2 program, version 1.5 (Juggins, 2007).

\section{Results}

\subsection{Hydrological connectivity, catchment alteration and climate records}

The time series of river-lake connectivity for the duration of 1968 2008 revealed considerable inter-annual variability (Fig. 2A). The period of 1968 to 2000 was characterized by years with extended periods of connectivity, with exception of low connectivity in 1971-72 and 1981. From 2000 to 2008, Adams Bayou experienced below average connectivity except in years 2002 and 2004. Also, in the last several decades increasing agricultural demands has led to substantial clearance of forested wetlands for rice cultivation in LWRF. The trend in land under rice cultivation increased for the study period, where most notable increase occurred during 1975-1980. These trends are reflected in the total land under cultivation and the corresponding increases in fertilizer usage (Fig. 2B). Total precipitation $(\mathrm{cm}$ ) also varied inter annually, with high values recorded in early 1970s and 1990s, followed by an extended duration of mostly low precipitation from 1990s to 2008 (Fig. 2C).
Mostly, cooler air temperatures were recorded in the 1960s and 1970 s, followed by steady increase in air temperature since the late 1990s.

\subsection{Sediment chronology}

Initial core description showed that the core was mostly composed of silt and clay. The sediment core graded from dark brown color, abundant in leaf litter to light brown and completely devoid of leaf debris. The X-ray scan (not shown here) and initial core description did not show signs of bioturbation in the sediment core. A well-defined 137Cs peak was observed at a depth of $36.5 \mathrm{~cm}$ that almost certainly records the 1963 fallout maximum from the atmospheric testing of nuclear weapons (Fig. 3A). Infinite small steps of exponential decay of 137Cs inventory also showed absence of mixing or bioturbation in the core post 1963 (Walling et al., 2002). Unsupported 210Pb concentrations declined irregularly with depth, with several monotonic features suggesting periods of accelerated sedimentation. The total and supported $210 \mathrm{~Pb}$ reached equilibrium at a depth of $48.5 \mathrm{~cm}$ (Fig. 3A-B). The model results showed that the mean sediment accumulation rate (SAR) since $1963(36.5 \mathrm{~cm})$ was $0.34 \mathrm{~g} \mathrm{~cm}^{-2} \mathrm{y}^{-1}$. The SAR was highest during the years 1977-1979, followed by high SAR the early 1990s. The lowest SAR was recorded between 2000 and 2007 (Fig. 3C).

\subsection{Diatom stratigraphy and sediment geochemistry}

We identified 22 genera and 55 species of sub-fossil diatoms from the Adams Bayou sediment core. The fossil assemblages were divided into three diatom assemblage zones (DAZ) (Fig. 4A). The DAZ1 (32.5$22.5 \mathrm{~cm}$; estimated: 1968-1985) was dominated by the benthic and
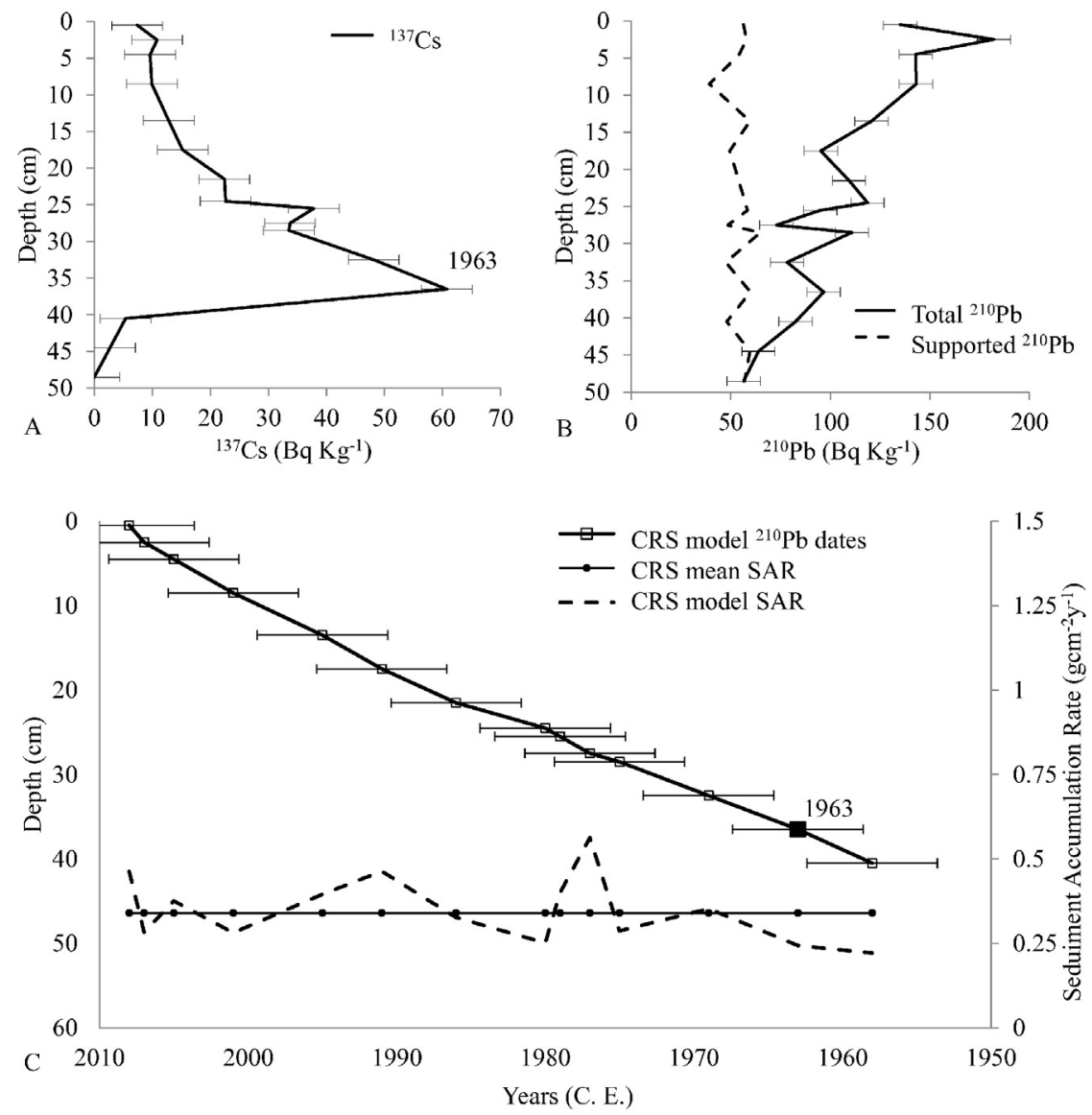

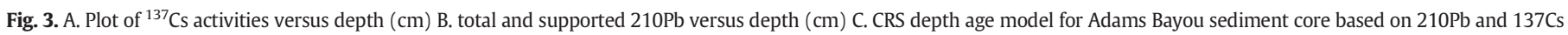
values. SAR refers to Sediment accumulation rates. 

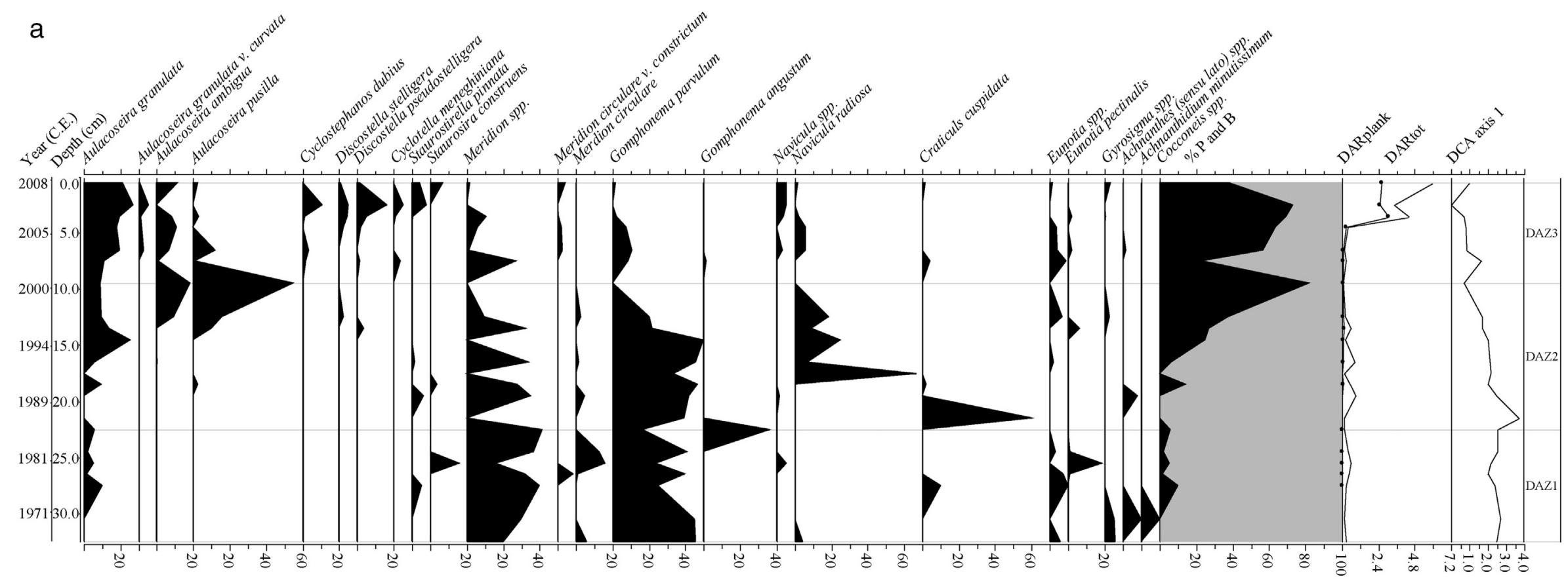

b

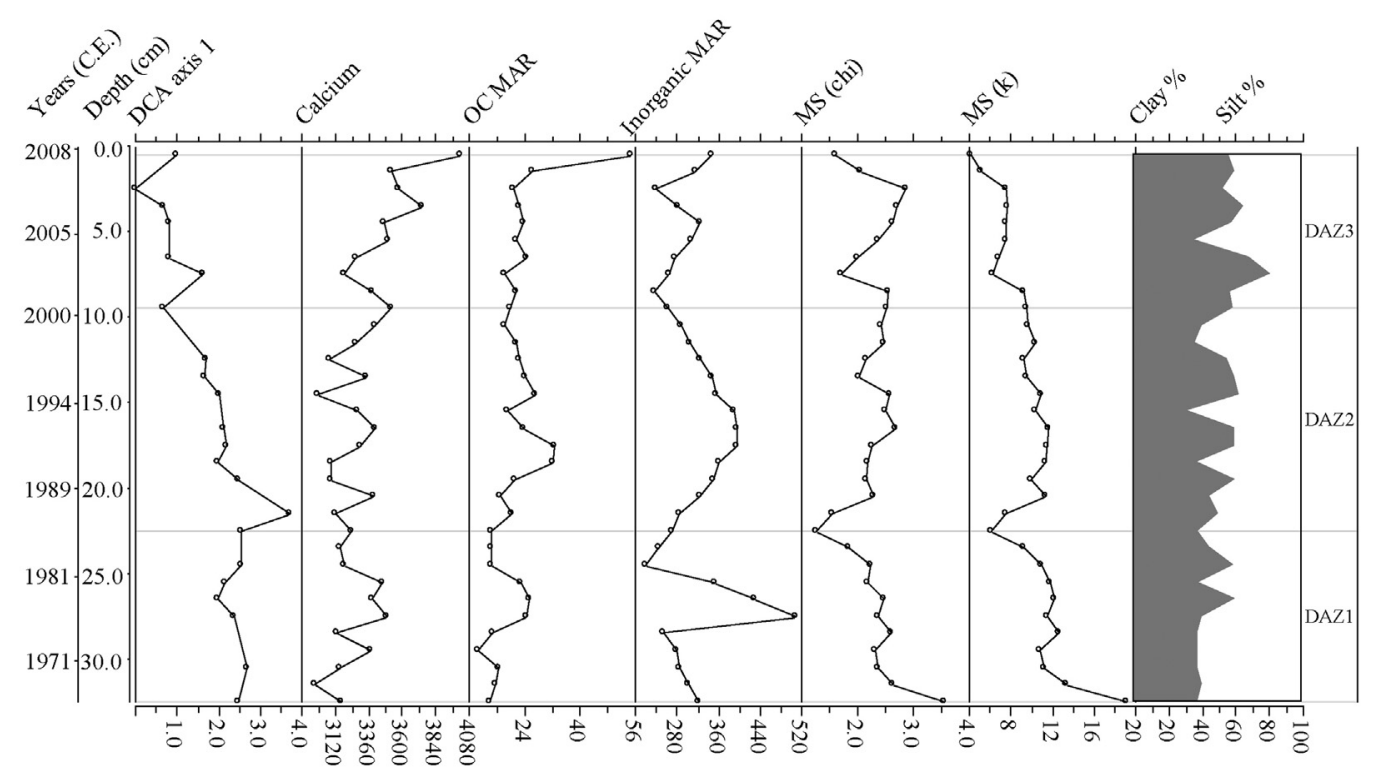

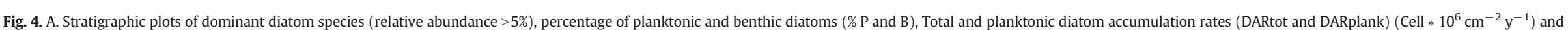

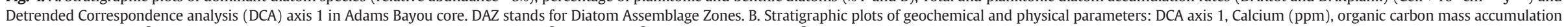
rate (OC MAR, mg/ $\mathrm{cm}^{2} \mathrm{yr}$ ), inorganic mass accumulation rate (Inorganic MAR, $\left.\mathrm{mg} / \mathrm{cm}^{2} \mathrm{yr}\right)$, mass $\left(\mathrm{m}^{3} / \mathrm{kg}\right.$ ) and volume $\left(\times 10^{-5} \mathrm{SI}\right)$ magnetic susceptibility (MS), \% clay and \% silt in Adams Bayou Core. 
epiphytic diatom species Meridion circulare (GREVILle) AgaRdH, Meridion spp., Gomphonema parvulum (KüTZING) KüTZING, and Gomphonema angustum AGARDH. Meridion spp. and G. parvulum were the only diatoms to be present throughout DAZ1. Both Meridion spp. and G. parvulum represented $16-45 \%$ of the relative abundance of valves in DAZ1. Eunotia spp. and Eunotia pectinalis (KÜTZING) RABENHORST were the other prominent epiphytic diatoms. In this zone, the facultative planktonic species were very sparse and lowest in abundance; Staurosirella pinnata (EHRENBERG) Williams AND ROUnd and Staurosira construens EHRENBERG were the only prominent species recorded. The relative abundance of planktonic diatoms was also low in DAZ1. Aulacoseira granulata (EHRENBERG) SiMONSEN was the only abundant planktonic species, ranging between 2 and $10 \%$ of valves. The DARplank values were lowest in this zone $\left(<1 * 10^{6}\right.$ cells $\left.\mathrm{cm}^{-2} \mathrm{y}^{-1}\right)$. The DARtotal ranged from 1.6-3.6 $* 10^{6}$ cells $\mathrm{cm}^{-2} \mathrm{y}^{-1}$ with the highest value observed at $2.6 \mathrm{~cm}$ depth (1978).

In DAZ2 (22.5-9.5 cm; estimated: 1985-2000), the relative abundance of benthic and epiphytic diatoms was higher than the planktonic diatoms. G. parvulum and Meridion spp. were the most predominant benthic species with relative abundance ranging between 20 and 50\% and $17-35 \%$, respectively. Some of the other abundant benthic species recorded were $M$. circulare, Navicula radiosa KüTzING and Craticula cuspidata (Kutzing) D.G. Mann. Amongst planktonic diatoms, A. granulata and Aulacoseira pusilla (MeISTER) Tuji AND Houk were the most abundant. Very low abundances of the planktonic forms Aulacoseira ambigua (GRUnow) SIMONSEN, Discostella stelligera (CLEVE AND GRUNOW) Houk AND KleE and Discostella pseudostelligera (Hustedt) Houk \& KLeE were also recorded. The relative abundance of benthic and epiphytic diatoms decreased towards the top of this zone, which was concurrent with the appearance of planktonic diatoms. The relative abundance of facultative planktonic diatom was also low in DAZ2. The DARtot was relatively higher and more variable than DAZ1 and ranged between 12.5 and $21.5 * 10^{6}$ cells $\mathrm{cm}^{-2} \mathrm{y}^{-1}$, with the highest values recorded around late 1980s and early 1990s. However, the DARplank still accounted for $<1.5 * 10^{6}$ cells $\mathrm{cm}^{-2} \mathrm{y}^{-1}$, but the values increased towards the top of this zone.

In DAZ3 (9.5-0.5 cm; estimated: 2000-2008), planktonic diatoms were most abundant. The relative abundance of planktonic diatoms ranged from $25 \%$ to $82 \%$, which was substantial higher than in DAZ 1 and 2 . The most abundant planktonic diatoms were $A$. granulata, $A$. pusilla and $A$. ambigua, followed by $D$. pseudostelligera and $D$. stelligera. Planktonic diatoms A. granulata var. curvata (HuSTEDT) SIMONSEN, Cyclostephanos dubius (FRICKE) ROUND IN THERIOT and Cyclotella meneghiniana KüTzING were also recorded in low abundances in this zone. Other planktonic diatoms (not shown in Fig. 5A), such as Cyclostephanos invisitatus (Hohn \& Hellermann) Theriot, Stoermer \& HÅKASSON, Stephanodiscus parvus STOERMER \& HÅKASSON and Stephanodiscus hantzschii Grunow, were recorded for the first time in this zone (abundances $<2 \%$ ). Meridion spp. and $G$. parvulum were still the most prominent benthic/epiphytic species, however their abundances were lowest in this zone. The DARtot increased around 2000, followed by a steep increase from 2004 to the top of this zone. The increase in DARtot in this zone was due to high DARplank, which increased from 0.23 to $\sim 6 * 10^{6}$ cells $\mathrm{cm}^{-2} \mathrm{y}^{-1}$.

During 1968-2000, both MS (k) and MS (chi) values were variable with higher values observed in late 1970s and early 1990s (Fig 4B). The \% silt and Inorganic MAR content were also variable in this duration. However, post 2000, a more prominent decrease was observed in MS, \% silt and Inorganic MAR. In contrast, the OC MAR and calcium $(\mathrm{Ca})$ values increased towards the top of the sediment core.

\subsection{Ordination analyses}

The DCA of fossil diatom assemblages showed that the gradient length of the first DCA axis was 3.72 SD, which indicated high beta diversity in the data set. The DCA axis 1 represented the principal changes in diatom assemblages over the past 40 years; and thus log normalized DCA axis 1 was used for conducting the change point analysis. A statistically significant shift in mean was identified in 2000, which confirmed Adams Bayou's transition to an alternate state. Further, the CCA conducted on fossil diatom assemblage showed that the main gradients represented by axes 1 and 2, explained 26 and $12.4 \%$ variance, respectively (Fig. 5A-B). The samples from 1968 to 2000, abundant in benthic and epiphytic diatoms, such as G. parvulum, M. circulare, Meridion spp. and Achnanthes (sensu lato) spp. were located along the positive CCA axis 1; and driven by MS (k) and \% silt. Whereas, samples from 2000 to 2008 , abundant in the planktonic diatoms A. ambigua, A. granulata, were located around the negative CCA axis 1 and influenced by cultivated area, OC MAR and air temperature. Other planktonic species, such as C. dubius, D. pseudostelligera, C. meneghiniana were also located close to the negative CCA axis 1 . The constrained-CCA further revealed that the environmental variables explained $49 \%$ variance in the diatom data. MS (k), \% silt, cultivated area, and air temperature, were selected as the most significant variables, and uniquely explained $6.9 \%, 5.0 \%, 4.5 \%$, and $4.2 \%$ variance, respectively.

\section{Discussion}

\subsection{Response to hydrological connectivity and catchment alterations}

During 1968-to late 1990s, Adams Bayou experienced higher than average connectivity with LWR. In the meantime, LWRF also underwent land clearance events, more prominently in mid-late 1970s. The land clearing and large-scale connectivity events were best represented by the variability in MS $(\mathrm{k} ; 6.9 \%, p<0.05)$ and $\%$ silt $(5 \%, p<0.05)$, respectively. Peaks in MS indicated higher ferromagnetic influxes, as a result of higher catchment erosion and hydrological variability (Dearing, 1999; McLauchlan, 2003); whereas, \% silt is known to effectively indicate water level fluctuation and hydrological connectivity (Liu et al., 2012; Chen et al., 2013). Respective peaks in SAR and Inorganic MAR further corroborated these alterations.

Higher connectivity and catchment alteration were also reflected by the presence of benthic (e.g., G. parvulum, M. circulare, Meridion spp.) and epiphytic diatoms (e.g., E. pectinalis and Eunotia spp.) that prefer to grow in clear and flowing fresh water (Patrick and Reimer, 1975; Grabowska et al., 2014). Further, the presence of $A$. granulata, a planktonic and thickly silicified diatom that thrives in turbulent and meso-eutrophic conditions serves as an indicator of connectivity with turbid rivers (Van Dam et al., 1994; Gell et al., 2002; Reid and Ogden, 2009; Grundell et al., 2012). These results signified that Adams Bayou was hydrologically connected and slightly nutrient enriched. The slight increase in DARplank and OC MAR, which is a reliable indicator of primary productivity and lake nutrient condition (Meyers, 1997; Chen et al., 2013) also supported the nutrient replete and productive lake conditions in late 1970s.

Subsequently, in the late 1990s, Adams Bayou experienced longer duration connectivity events associated with several large floods. In accordance to Adams Bayou's higher state of connectivity, higher abundances of Meridion spp. and G. parvulum and low abundance of $M$. circulare were recorded in the sediment core. Higher abundances of benthic $N$. radiosa and C. cuspidata, known to grow in well aerated, oxygenated and mesotrophic water, were also recorded during this period (Cholnoky, 1966; O'Farrell, 1994; Van Dam et al., 1994; Zhang et al., 2011). Corresponding peaks in MS (k) and \% silt were also observed. Between late 1990s-2000s, the duration of connectivity began to decrease (Figs. 4, 5) with a subsequent prevalence of planktonic diatoms. The abundance of planktonic diatoms, such as A. granulata, A. pusilla, A. ambigua, D. stelligera and D. pseudostelligera, indicated Adams Bayou's shift towards to a slightly turbid and nutrient enriched ecological state (Denys et al., 2003; Kiss et al., 2012).

After 2000s, the connectivity between Adams Bayou and LWR was the lowest due to several extended dry periods (Figs. 4, 5). 

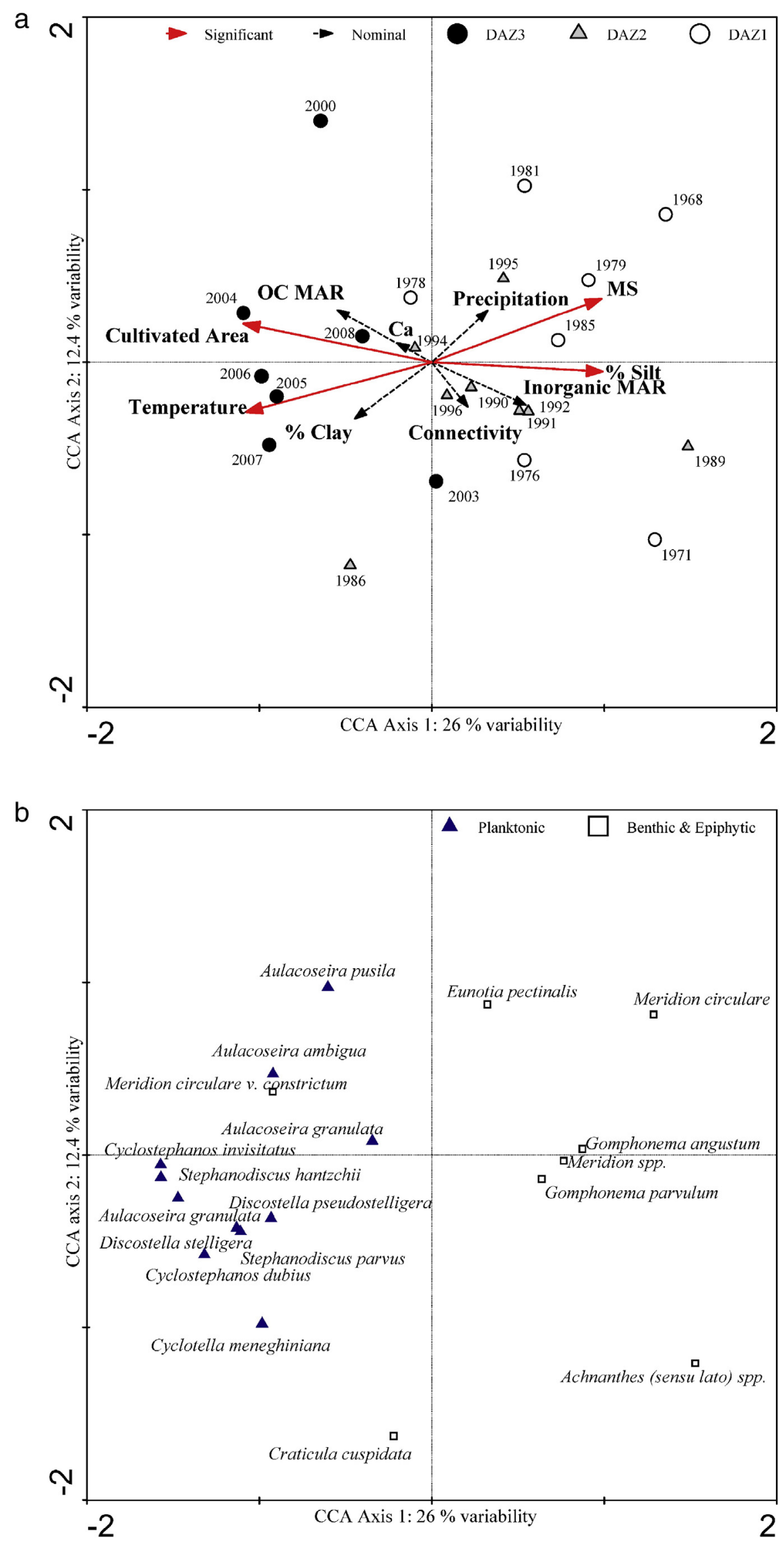

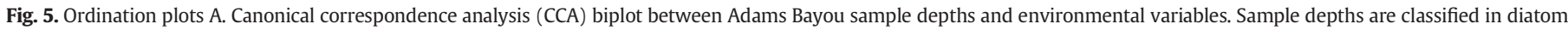

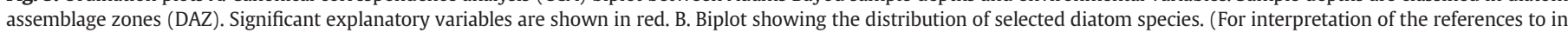
this figure legend, the reader is referred to the web version of this article.) 
Simultaneously, intensifications in cultivation $(4.5 \% ; p<0.05)$ and accompanying increase in fertilizer usage significantly affected the diatom assemblages and lake ecosystem. Clearly, the condition of the floodplain had shifted to favor phytoplankton at the expense of benthic and epiphytic taxa that favor a deep photic zone. The prevalence of nutrient tolerant, planktonic diatoms: A. pusilla, and A. ambigua along with the presence of known eutrophic indicators, such as $C$. meneghiniana, $C$. invisitatus, S. parvus and S. hantzschii in low abundances, signified that Adams Bayou might have entered a nutrient enriched state (Potapova and Charles, 2007; Van Dam et al., 1994). We also recorded higher abundance of planktonic $A$. granulata v. curvata and A. granulata that typically grow in turbulent water conditions; however, their higher abundance during low connectivity state indicated that light limitation and higher nutrient availability might be providing conditions to their advantage (Davey, 1987; Van Dam et al., 1994; Siver and Kling, 1997 and Trifonova and Genkal, 2001). Therefore, an increase in the abundance of Aulacoseira varieties, in addition to higher abundance of other nutrient tolerant, planktonic diatoms characterized the change in Adams Bayou's ecological conditions from a well-connected, mesotrophic lake to an isolated, light limited and eutrophic lake. A productive and nutrient replete system was also indicated by the exponential increase in DARplank, Ca and OC MAR (Whitmore, 1989; Cohen, 2003; Croudace et al., 2006; Giralt et al., 2011; Figs. 4, 5). A subsequent decrease in MS and \% silt towards the surface of the sediment core further provided evidence for Adams Bayou's transition into an shallow, isolated, light limited system with higher levels of productivity. The reduction in MS (k) could possibly be due to decrease in catchment erosion and hydrological stabilization, post river modification (Dearing, 1999; McLauchlan, 2003). The substantial reduction in MS (k) after 2000s could also be attributed to the increase in organic matter loading in Adams Bayou (McLauchlan, 2003; Reid et al., 2007). Whereas, the decrease in \% silt after 2000s could be due to reduced lake flushing and longer residence times promoting slow sedimentation of finer sediment lake (Wren et al., 2008; Heath and Plater, 2010; Liu et al., 2012).

Our results are contrary to some shallow floodplain lakes that respond to low levels of hydrological connectivity with an increase in water transparency, reduction in nutrient levels, and prevalence of benthic and epiphytic diatoms (e.g. Liu et al., 2012; Sokal et al., 2010). In Adams Bayou the decrease in connectivity caused an increase in turbidity, nutrient concentrations and a reduction in benthic and epiphytic diatom assemblages. We speculate that reduced hydraulic flushing and longer residence time, in combination with increased agriculture and fertilizer usage, could have contributed to Adams Bayou's turbid and nutrient rich state (Rippey et al., 1997; Kangur et al., 2007; Heath and Plater, 2010). With a reduction in external sediment inputs, shading by phytoplankton and dissolved organic carbon can also contribute to light limitation in eutrophic lakes, such as Adams Bayou (Cole et al., 1998; Vaehaetalo et al., 2005). Further, light limitation and higher nutrient availability can provide growth advantage to nutrient tolerant, planktonic diatoms and obstruct the growth of benthic and epiphytic diatoms (Reid et al., 2007). These findings were in accordance with the ecosystem regime shift models (Scheffer et al., 1993; Scheffer and Carpenter, 2003) and similar observations noted in shallow floodplain lakes elsewhere (c.f. Capon et al., 2015).

\subsection{Other potential drivers}

Global circulation models predict increases in air temperature and hydrological extremes for most part of United States (IPCC, 2014). Recent studies suggest that changes in precipitation patterns can significantly influence the water quality for range of aquatic habitats (e.g., Whitehead et al., 2009; Singh et al., 2016). Increase in large precipitation events and associated flooding can mobilize pollutants from the cultivated sections of RFEs and can adversely impact water quality and productivity of floodplain lakes (Knight et al., 2007; Kröger et al., 2013). In our study, precipitation did not directly influence the diatom assemblages in Adams Bayou. However, the temporal pattern of precipitation was correlated to the duration of connectivity, which had a significant influence on Adams Bayou's diatom variability (see Section 5.1, Fig. 5B-C). Similarly, air temperature also significantly explained the diatom variability in Adams Bayou, specifically after 2000. Studies suggest that rising air temperature can influence the nutrient dynamics, phytoplankton community structure and primary productivity (Jensen and Andersen, 1992; Schindler, 2006), of temperate and tropical floodplain lakes (Hamilton, 2010; Chen et al., 2013). However, in LWRF, hydrological variability and anthropogenic overprinting emerged as the most significant drivers. Nonetheless, the influence of climate forcing can be crucial and requires further exploration.

\section{Conclusion}

The paleo-ecological information provided here offers crucial insights into the role of human-induced hydrological change, catchment development and potential climate variability on the condition of one bayou within the Cache-Lower White River Ramsar site. The natural ecological condition of this studied lake shifted from a mesotrophic, clear water system driven by benthic and epiphytic algal communities to a community dominated by phytoplankton reflective of an enriched, turbid water body. It is evident that the ecological character of this site has changed negatively, and is outside its historical range of variability, necessitates notification to the Ramsar Secretariat. Our findings highlights the necessity to monitor river-wetland systems, especially sites as rarely studies as the LWRF. Even though establishing robust chronologies for may be challenging in these anthropogenically altered and actively flooding RFEs. Careful site selection and sampling of a suite of lakes with different hydrological and land-use controls might provide robust chronological sequences to assess the degree and time of change in the RFE; therefore allowing implementation of required remediation measures.

Supplementary data to this article can be found online at http://dx. doi.org/10.1016/j.scitotenv.2016.06.174.

\section{Acknowledgements}

This study would not have been possible without the financial support by DEB NSF-0836131 (awarded to Sonja Hausmann, Stephen K. Boss and Ruchi Bhattacharya). We are also thankful for funding provided by the Geological Society of America graduate student research grant, graduate assistantship in the Environmental Dynamics program, and Doctoral Academy Fellowship from the University of Arkansas Graduate School to Ruchi Bhattacharya.

\section{References}

Anderson, N.J., 1989. A whole-basin diatom accumulation rate for a small eutrophic lake in Northern Ireland and its palaeoecological implications. J. Ecol. 926-946.

Appleby, P.G., Smol, J.P., 2001. Chronostratigraphic techniques in recent sediments. In: Last, W.M. (Ed.), Tracking environmental change using Lake sedimentsBasin Analysis, Coring, and Chronological Techniques vol. 3. Kluwer Academic Publishers, Dordrecht, The Netherlands, pp. 171-203.

Appleby, P.G., Nolan, P.J., Gifford, D.W., Godfrey, M.J., Oldfield, F., Anderson, N.J., Batterbee, R.W., 1986. 210Pb dating by low background gamma counting. Hydrobiologia 141, 21-27.

Battarbee, R.W., Jones, V.J., Flower, R.J., Cameron, N.G., Bennion, H., Carvalho, L., Juggins, S., 2001. Diatoms. In: Smol, J.P., Birks, H.J.B., Last, W.M. (Eds.), Tracking environmental change using Lake sedimentsTerrestrial, Algal, and Siliceous Indicators vol. 3. Kluwer Academic Publishers, Dordrecht, The Netherlands, pp. 155-202.

Bhattacharya, R., 2012. The use of diatoms to infer environmental change of the lower White River, southeastern Arkansas (Ph.D. Dissertation) University of Arkansas, Fayetteville.

Brugam, R., Bala, I., Martin, I., Vermillion, B., Retzlaff, W., 2003. The Sedimentary Record of Environmental Contamination in Horseshoe Lake, Madison County, Illinois. Transactions of the Illinois State Academy of Science Vol. 96 pp. 205-217.

Capon, S.I., Lynch, A.I.I., Bond, N., Chessman, B., Davis, J., Davidson, N., Finlayson, M., Gell, P., Hohnberg, D., Humphrey, C., Kingsford, R., Nielsen, D., Ward, K., Thomson, J., Mac Nally, R., 2015. Regime shifts, thresholds and multiple stable states in freshwater ecosystems; a critical appraisal of the evidence. Sci. Total Environ. 534, 122-130. 
Chen, X., Yang, X., Dong, X., Liu, Q., 2011. Nutrient dynamics linked to hydrological condition and anthropogenic nutrient loading in Chaohu Lake (southeast China). Hydrobiologia 661, 223-234.

Chen, X., Yang, X., Dong, X., Liu, E., 2013. Environmental Changes in Chaohu Lake (southeast, China) Since the mid 20th century: the Interactive Impacts Of Nutrients, Hydrology and Climate. Limnologica-Ecology and Management of Inland Waters Vol. 43 pp. $10-17$.

Cholnoky, B.J., 1966. Die diatomeen im unterlaufe des okawango-flusse. Diatomaceae INova Hedwigia Heft Vol. 21. Verlag von J. Cramer, Lehre, pp. 1-122.

Cohen, A.S., 2003. Paleolimnology: The history and evolution of lake systems. Oxford University Press, New York, p. 500

Cole, J.J., Kitcheii, J.F., Pace, M.L., 1998. Impact of dissolved organic carbon, phosphorus, and grazing on phytoplankton biomass and production in experimental lakes Stephen R. Carpenter. Limnol. Oceanogr. 43, 73-80.

Craig, M.A., Kitchen, W.E., Wise, W.R., 2001. Analysis of Hydrologic Data for the White River basin. Final Report on Research Work Order no. 203Fisheries and Aquatic Sciences. University of Florida, Gainesville, p. 10.

Croudace, I.W., Rindby, A., Rothwell, R.G., 2006. ITRAX: description and evaluation of a new multi-function X-ray core scanner. Geol. Soc. Lond. Spec. Publ. 267, 51-63.

Davey, M.C., 1987. Seasonal-variation in the filament morphology of the freshwater diatom Melosira granulata (Ehrenb) Ralfs. Freshw. Biol. 18, 5-16.

Dean, W.E., 1974. Determination of carbonate and organic-matter in calcareous sediments and sedimentary-rocks by loss on ignition-comparison with other methods. J. Sediment. Res. 44, 242-248.

Dearing, J.A., 1999. Holocene environmental change from magnetic proxies in lake sediments. In: Maher, B.A., Thompson, R. (Eds.), Quaternary Climates, Environments and Magnetism, pp. 231-278.

Denys, L., Muylaert, K., Krammer, K., Joosten, T., Reid, M., Rioual, P., 2003. Aulacoseira subborealis stat. nov. (Bacillariophyceae): a common but neglected plankton diatom. Nova Hedwigia 77, 407-427.

Downing, J.A., Cole, J.J., Middelburg, J.J., Striegl, R.G., Duarte, C.M., Kortelainen, P., Prairie, Y.T., Laube, K.A., 2008. Sediment organic carbon burial in agriculturally eutrophic impoundments over the last century. Glob. Biogeochem. Cycles 22, GB1018.

Finlayson, C.M., Clarke, S.J., Davidson, N.C., Gell, P., 2016. Role of palaeoecology in describing the ecological character of wetlands. Mar. Freshw. Res. 67, 687-694.

Gell, P.A., Sluiter, I.R., Fluin, I., 2002. Seasonal and interannual variation in diatom assemblages in Murray River connected wetlands in northwest Victoria, Australia. Mar. Freshw. Res. 53, 981-992.

Gell, P., Tibby, I., Fluin, I., Leahy, P., Reid, M., Adamson, K., Bulpin, S., MacGregor, A., Wallbrink, P., Hancock, G., Walsh, B., 2005. Accessing limnological change and variability using fossil diatom assemblages, south-east Australia. River Res. Appl. 21, 257-269.

Giralt, S., Rico-Herrero, M.T., Vega, I.C., Valero-Garces, B.L., 2011. Quantitative climate reconstruction linking meteorological, limnological and XRF core scanner datasets: the Lake Sanabria case study, NW Spain. J. Paleolimnol. 46, 487-502.

Grabowska, M., Glińska-Lewczuk, K., Obolewski, K., Burandt, P., Kobus, S., Dunalska, J., Kujawa, R., Goździejewska, A., Skrzypczak, A., 2014. Effects of hydrological and physicochemical factors on phytoplankton communities in floodplain lakes. Pol. J. Environ. Stud. 23, 713-721.

Grimm, E.C., 1987. CONISS: a FORTRAN 77 program for stratigraphically constrained cluster analysis by the method of incremental sum of squares. Comput. Geosci. 13, 13-35.

Grundell, R., Gell, P., Mills, K., Zawadzki, A., 2012. Interaction between a river and its wetland: evidence from the Murray River for spatial variability in diatom and radioisotope records. J. Paleolimnol. 47, 205-219.

Hamilton, S.K., 2010. Biogeochemical implications of climate change for tropical rivers and floodplains. Global Change and River Ecosystems-Implications for Structure, Function and Ecosystem Services. Springer, Netherlands, pp. 19-35.

Hausmann, S., Hall, R., Gell, P., 2011. Floodplain Lakes: evolution and response. EOS Trans. Am. Geophys. Union 92, 154

Heath, S.K., Plater, A.J., 2010. Records of pan (floodplain wetland) sedimentation as an approach for post-hoc investigation of the hydrological impacts of dam impoundment: the Pongolo River, KwaZulu-Natal. Water Res. 44, 4226-4240.

Heiri, O., Lotter, A.F., Lemcke, G., 2001. Loss on ignition as a method for estimating organic and carbonate content in sediments: reproducibility and comparability of results. J. Paleolimnol. 25, 101-110.

Hustedt, F., 1930. In: Pascher, A. (Ed.), Die Susswasserflora Mitteleuropas, second ed Bacillariophyta (Diatomeae) Vol. Heft 10. Verlag von Gustav Fischer, Germany, p. 466

Hustedt, F., 1977. Die Kieselalgen. Otto Koelts Science Publishers, Koenigstein, Germany.

IPCC. (Intergovernmental Panel on Climate Change), 2014. IPCC, 2014: Climate change 2014: Impacts, adaptation, and vulnerability. In: Field, CB, Barros, V. R, Dokken, D.J., Mach, K.J., Mastrandrea, M.D., Bilir, T.E., Chatterjee, M., Ebi, K.L., Estrada, Y.O. Genova, R.C., Girma, B. (Eds.), Part A: Global and Sectoral Aspects. Contribution of Working Group II to the Fifth Assessment Report of the Intergovernmental Panel on Climate Change (2014).

Jensen, H.S., Andersen, F.O., 1992. Importance of temperature, nitrate, and pH for phosphate release from aerobic sediments of four shallow, eutrophic lakes. Limnol Oceanogr. 37, 577-589.

Jongman, R.H.G., Ter Braak, C.J.F., Van Tongeren, O.F.R., 1995. Data Analysis in Community and Landscape Ecology. Cambridge University Press.

Juggins, S., 2007. C2 version 1.5 user guide. Software for Ecological and Palaeoecological Data Analysis and Visualisation. Newcastle University, Newcastle upon Tyne, UK, p. 73.

Kangur, M., Kangur, K., Laugaste, R., Punning, J.M., Möls, T., 2007. Combining limnological and palaeolimnological approaches in assessing degradation of Lake Pskov. Hydrobiologia 584, 121-132.
Kattel, G., Gell, P., Perga, M.E., Jeppesen, E., Grundell, R., Weller, S., Zawadzki, A., Barry, L. 2015. Tracking a century of change in trophic structure and dynamics in a floodplain wetland: integrating palaeoecological and palaeoisotopic evidence. Freshw. Biol. 60, 11-723. http://dx.doi.org/10.1111/FWB.12521.

Killick, R., Eckley, I., 2014. Changepoint: an R package for changepoint analysis. J. Stat, Softw. 58, 1-19,

King, S.L., Allen, J.A., McCoy, J.W., 1998. Long-term effects of a lock and dam and Greentree reservoir management on a bottomland hardwood forest. For. Ecol. Manag. 112 213-226.

Kiss, K.T., Klee, R., Ector, L., Ács, É., 2012. Centric diatoms of large rivers and tributaries in Hungary: morphology and biogeographic distribution. Acta Bot. Croat. 71, 311-363.

Knight, S.S. Lizotte, R.E. Smith, S. Bryant, C.T. 2007. Distribution and spatial variation in surface sediment pesticides of Mississippi alluvial plain. J. Int. Environ. Appl. Sci. 2, $40-50$.

Krammer, K. Lange-Bertalot, H., 1986-1991. Bacillariophyceae. Susswasserflora von Mitteleuropa. Gustav Fischer Verlag, Stuttgart (Band 2(1-4). Vols 1-4 Tiel 1(1986, pp. 876) 2(1988, pp. 596) 3(1991, pp. 576) 4(1991, pp. 437)).

Kröger, R., Dunne, E.J., Novak, J., King, K.W., McLellan, E., Smith, D.R., Strock, J., Boomer, K., Tomer, M., Noe, G.B., 2013. Downstream approaches to phosphorus management in agricultural landscapes: Regional applicability and use. Publications from USDAARS/UNL Faculty. Paper 1384

Lesack, L.F., Marsh, P. 2010. River-to-lake connectivities, water renewal, and aquatic habitat diversity in the Mackenzie River Delta. Water Resour. Res. 46 (12). http://dx.doi. org/10.1029/2010WR009607.

Lin, L., 2009. Final Report: White River Basin Comprehensive Study: Development of Unsteady-State Model. Unpublished report to US Army Corps of Engineers http://www. mvm.usace.army.mil/Portals/51/docs/PPPMD/White\%20River\%20Study/ unsteadystate_model_wrb.pdf.

Liu, Q.. Yang. X.. Anderson, N.J. Liu, E. Dong, X.. 2012. Diatom ecological response to altered hydrological forcing of a shallow lake on the Yangtze floodplain, SE China. Ecohydrology 2, 316-325.

MacDonald, P.O., Frayer, W.E., Clauser, J.K., 1979. Documentation, chronology, and future projections of bottomland hardwood loss in the lower Mississippi alluvial plain. Performed for the division of ecological services, U.S. Fish and Wildlife Service. HRBSinger, Inc., State College, PA.

McClunev, K.E., Poff, N.L. Palmer, M.A., Thorp, J.H., Poole, G.C., Williams, B.S., Williams, M.R., Baron, J.S., 2014. Riverine macrosystems ecology: sensitivity, resistance, and resilience of whole river basins with human alterations. Front. Ecol. Environ. 12, 48-58,

McLauchlan, K., 2003. Plant cultivation and forest clearance by prehistoric North Americans: pollen evidence from Fort Ancient, Ohio, USA. The Holocene 13, 557-566.

Meyers, P.A., 1997. Organic geochemical proxies of paleoceanographic, paleolimnologic and paleoclimatic processes. Org. Geochem. 27, 213-250.

Newall P, Lloyd L, Gell P. Walker K. 2016. Implications of environmental trajectories on limits of acceptable change: a case study of the Riverland Ramsar Site, South Australia. Mar. Freshw. Res., doi.org/http://dx.doi.org/10.1071/MF14187

Nilsson, C., Berggren, K., 2000. Alterations of riparian ecosystems caused by river regulation. Bioscience 50, 783-792.

NOAA (National Oceanic and Atmospheric Administration), 2014. http://www.ncdc.noaa. gov/cag/.

O'Farrell, I., 1994. Comparative analysis of the phytoplankton of fifteen lowland fluvial systems of the River Plate Basin (Argentina). Hydrobiologia 289, 109-117.

Oksanen, I., Kindt, R., Legendre, P., O'Hara, B., Simpson, G.L., Solymos, P., Stevens, M.H.H. Wagner, H., 2008. Vegan: Community ecology package. R package version 1 (15-0. http://cran.r-project.org/, http://vegan.r-forge.r-project.org/).

Patrick, R., Reimer, C.W., 1966. The diatoms of the United States, exclusive of Alaska and Hawaii, Volume 1-Fragilariaceae, Eunotiaceae, Achnanthaceae, Naviculaceae. Acad. Natl. Sci. Phila. Monogr. 13, 688.

Patrick, R., Reimer, C.W., 1975. The diatoms of the United States, exclusive of Alaska and Hawaii, Volume 2, Part 1-Entomoneidaceae, Cymbellaceae, Gomphonemaceae, Epithemaceae. Acad. Natl. Sci. Phila. Monogr. 13, 213.

Potapova, M., Charles, D.F., 2007. Diatom metrics for monitoring eutrophication in rivers of the United States. Ecol. Indic. 7, 48-70.

$\mathrm{R}$ Development Core Team, 2008. R: A language and environment for statistical computing. R Foundation for Statistical Computing, Vienna, Austria (ISBN 3-900051-07-0, URL http://www.R-project.org).

Reavie, E.D., Edlund, M.B., 2010. Diatoms as indicators of long term environmental change in rivers, fluvial lakes, and impoundments. In: Smol, J.P., Stoermer, J.P. (Eds.), The diatoms: Applications for environmental and earth sciences, second ed., pp. 86-97 (Cambridge).

Reid, M.A., Ogden, R.W., 2009. Factors affecting diatom distribution in floodplain lakes of the southeast Murray Basin, Australia and implications for palaeolimnological studies. J. Paleolimnol. 41, 453-470.

Reid, M.A., Sayer, C.D., Kershaw, A.P., Heijnis, H., 2007. Palaeolimnological evidence for submerged plant loss in a floodplain lake associated with accelerated catchment soil erosion (Murray River, Australia). J. Paleolimnol. 38, 191-208.

Rippey, B.N., Anderson, N.M., Foy, R.H., 1997. Accuracy of diatom-inferred total phosphorus concentrations and the accelerated eutrophication of a lake due to reduced flushing and increased internal loading. Can. J. Fish. Aquat. Sci. 54, 2637-2646.

Rodríguez, P., Tell, G., Pizarro, H., 2011. Epiphytic algal biodiversity in humic shallow lakes from the Lower Paraná River Basin (Argentina). Wetlands 31, 53-63.

Smith, F.L., Saucier, R.T., 1971. Geological investigations of the Western Lowlands area Lower Mississippi Valley: Vicksburg, Mississippi. U.S. Army Corps of Engineers Waterways Experiment Station Technical Report S-71-5.

Scheffer, M., Carpenter, S.R., 2003. Catastrophic regime shifts in ecosystems: linking theory to observation. Trends Ecol. Evol. 18, 648-656. http://dx.doi.org/10.1016/j.tree. 2003.09.002. 
Scheffer, M., Hosper, S.H., Meijer, M.L., Moss, B., Jeppesen, E., 1993. Alternative equilibria in shallow lakes. Trends Ecol. Evol. 8, 275-279. http://dx.doi.org/10.1016/01695347(93)90254-M.

Schindler, D.W., 2006. Recent advances in the understanding and management of eutrophication. Limnol. Oceanogr. 51, 356-363.

Scott, H.D., Ferguson, J.A., Hanson, L., Fugitt, T., Smith, F., 1998. Agricultural water management in the Mississippi Delta region of Arkansas. Arkansas Agricultural Experiment Station Research Bulletin Vol. 959.

Singh, N.K., Reyes, W.M., Bernhardt, E.S., Bhattacharya, R., Meyer, J.L., Knoepp, J.D., Emanuel, R.E., 2016. Hydro-climatological influences on long-term dissolved organic carbon in a mountain stream of the southeastern United States. J. Environ. Qual.

Siver, P.A., Kling, H., 1997. Morphological observations of Aulacoseira using scanning electron microscopy. Can. J. Bot. 75, 1807-1835.

Smilauer, P., 1992. CanoDraw: User's Guide, v. 3.0. Microcomputer Power.

Sokal, M.A., Hall, R.I., Wolfe, B.B., 2010. The role of flooding on inter-annual and seasona variability of lake water chemistry, phytoplankton diatom communities and macrophyte biomass in the Slave River Delta (Northwest Territories, Canada). Ecohydrology 3, 41-54.

Sparks, R.E., 1995. Need for ecosystem management of large rivers and their floodplains. Bioscience 45, 68-182.

ter Braak, C.J.F., 1986. Canonical correspondence analysis: a new eigenvector technique for multivariate direct gradient analysis. Ecology 67, 1167-1179.

ter Braak, C.J.F., Šmilauer, P., 2002. CANOCO Reference Manual and CanoDraw for Windows User's Guide: Software for Canonical Community Ordination (version 4.5). (www.canoco.com): Microcomputer Power, Ithaca, NY, USA.

Thomaz, S.M., Bini, L.M., Bozelli, R.L., 2007. Floods increase similarity among aquatic habitats in river-floodplain systems. Hydrobiologia 579, 1-13.

Tockner, K., Pusch, M., Borchardt, D., Lorang, M.S., 2010. Multiple stressors in coupled river-floodplain ecosystems. Freshw. Biol. 55, 135-151.

Tockner, K., Pusch, M., Gessner, J., Wolter, C., 2011. Domesticated ecosystems and nove communities: challenges for the management of large rivers. Ecohydrol. Hydrobiol. 11, 167-174.

Trifonova, I, Genkal, S., 2001. Species of the genus Aulacoseira Twaites in lakes and rivers of north-western Russia-distribution and ecology. Proceedings 16 international diatom symposium, Athens, pp. 315-323.
U.S. National Ramsar Committee, 2009. http://www.ramsarcommittee.us/Ramsar_Sites_ Brochure.

USDA (United States Department of Agriculture), 2016. National Agricultural Statistics Service (NASS). (Retrieved on: June 2016) http://www.nass.usda.gov.

USFWS (United States Fish and Wildlife Service), 1994. Comprehensive Management Plan for the Cache River and White River National Wildlife Refuges, within the Cache/ Lower White Rivers Ecosystem (131 pp.).

USFWS (United States Fish and Wildlife Services), 2008. White River National Wildlife Refuge: Briefing Book for Biological Review, August 4-8, 2008.

USFWS (United States Fish and Wildlife Services), 2010. U.S. Fish and Wildlife Services White River National Wildlife Refuge, Arkansas. (Retrieved on: October 2010) http://www.fws.gov/whiteriver/.

Vaehaetalo, A.V., Wetzel, R.G., Paerl, H.W., 2005. Light absorption by phytoplankton and chromophoric dissolved organic matter in the drainage basin and estuary of the Neuse River, North Carolina (USA). Freshw. Biol. 50, 477-493.

Van Dam, H., Mertens, A., Sinkeldam, J., 1994. A coded checklist and ecological indicator values of freshwater diatoms from the Netherlands. Neth. J. Aquat. Ecol. 28, 117-133.

Walling D.E. He, Q Appleby, P.G. 2002. Conversion models for use in soil-erosion, soilredistribution and sedimentation investigations. In: Zapata, F. (Ed.). Handbook for the assessment of soil erosion and sediment using environmental radionuclides. Kluwer Academic Publishers, Berlin, pp. 111-164.

Whitehead, P.G., Wilby, R.L., Battarbee, R.W., Kernan, M., Wade, A.J., 2009. A review of the potential impacts of climate change on surface water quality. Hydrol. Sci. J. 54, 101-123.

Whitmore, T.J., 1989. Florida diatom assemblages as indicators of trophic state and $\mathrm{pH}$, Limnol. Oceanogr. 34, 882-895.

Wilber, D.H., Tighe, R.E., O'Neil, L.J., 1996. Associations between changes in agriculture and hydrology in the Cache River basin, Arkansas, USA. Wetlands 16, 366-378.

Wolfe, B. Smol, J.P., 2005. Impact of climate and river flooding on the hydroecology of flood plain basin, peace-Athabasca Delta, Canada since 1700. Quat. Res. 6, 147-162.

Wren, D.G., Davidson, G.R., Walker, W.G., Galicki, S.J., 2008. The evolution of an oxbow lake in the Mississippi alluvial floodplain. J. Soil and Water Conserv. 63, 129-135.

Zhang, N., Fan, Y., Liu, Y., 2011. Relationship between diatom communities and environmental conditions at Honghe wetland, China. Afr. J. Biotechnol. 10 (17506-1751). 